\title{
SAMODEJEN ZAJEM IN ISKANJE SPREMEMB V TOPOGRAFSKEM SLOJU STAVB IZ DIGITALNEGA MODELA POVRŠJA IN MULTISPEKTRALNEGA ORTOFOTA
}

AUTOMATIC EXTRACTION AND BUILDING CHANGE DETECTION FROM DIGITAL SURFACE MODEL AND MULTISPECTRAL ORTHOPHOTO

\author{
Dejan Grigillo, Mojca Kosmatin Fras, Dušan Petrovič
}

UDK: 004.6:528.7:528.93:659.2

\section{IZVLEČEK}

Vzdrževanje podatkov $v$ topografskih bazah je ena od pomembnejših nalog organizacij, ki te podatkovne baze vodijo. Eden od pomembnih podatkovnih slojev $v$ topografskih bazah so podatki o stavbah. V članku sta opisani metoda za samodejen zajem stavb iz digitalnega modela površsja in multispektralnega ortofota ter uporaba rezultatov zajema za samodejno iskanje sprememb $v$ topografskih bazah, $v$ katerih se vodijo podatki o stavbah. Začetno masko stavb smo izdelali iz normaliziranega digitalnega modela površja (nDMP). Vegetacijo smo iz maske stavb izločili z modificiranim vegetacijskim indeksom, izračunanim iz infrardečega ortofota ob upoštevanju indeksa senc in teksture nDMP. Na končni maski smo stavbe vektorizirali z uporabo transformacije Radon. Rezultate samodejnega zajema stavb smo primerjali $s$ katastrom stavb in dejanskim stanjem na terenu. $S$ samodejnim postopkom smo našli 94,4\% vseh stavb na območju in ocenili, da je opisana metoda primerna za zajem podatkov o stavbah za topografske baze v merilih 1:10 000 in manj. Rezultat samodejnega iskanja sprememb (popolnost 93,5\% in pravilnost 78,4\%) kaže, da je opisana metoda primerna za iskanje sprememb med podatki o stavbah.

\section{KLJUČNE BESEDE}

samodejni zajem stavb, iskanje sprememb, normalizirani digitalni model površja, multispektralni ortofoto, modificiran vegetacijski indeks
Klasifikacija prispevka po COBISS-u: 1.01

\section{ABSTRACT}

The update of topographic databases is an important task for organizations that maintain them. Building data are one of the important data types in topographic databases. The article describes a method for automatic building extraction from digital surface model and multispectral orthophoto and the use of extraction results for the building change detection in the topographic database. The initial building mask was created from the normalized digital surface model (nDSM).Vegetation was eliminated from the building mask using a modified vegetation index calculated from the infrared orthophoto and also considering the shadow index and the nDMP texture. The final building mask was vectorised using Radon transform. The results of the automatic building extraction were compared to the building cadastre and the actual situation on the ground. The automatic method detected $94.4 \%$ of all buildings in the area. We concluded that the described method is appropriate for capturing of the building data for the topographic database in scales 1:10 000 and smaller. Automatic change detection results (completeness $93.5 \%$ and correctness 78.4\%) indicate that the described method is appropriate for building change detection.

\section{KEY WORDS}

automatic building extraction, change detection, normalised digital surface model, multispectral orthophoto, modified vegetation index 


\section{UVOD}

Slovenija je po osamosvojitvi leta 1991 delno prenovila in pretežno na novo vzpostavila sistem državnih topografskih kart in baz. Po letu 2000 je kot nadomestek za nekdanji temeljni topografski načrt (TTN) začela vzpostavljati bazo topografskih podatkov DTK 5, ki je najpodrobnejša topografska baza podatkov v vektorski obliki. Sloj stavb, ki je ena izmed objektnih skupin DTK 5, je bil privzet iz podatkov katastra stavb, v samem postopku zajema vsebine DTK 5 pa dopolnjen. Viri za osnovni zajem katastra stavb so bili fotogrametrični postopki ali terenske meritve, dopolnitev sloja stavb v okviru vzpostavitve DTK 5 pa je bila izvedena iz podatkov cikličnega aerosnemanja Slovenije (CAS). Po desetletju zajema je DTK 5 vzpostavljen na približno $60 \%$ površja Slovenije, ki pa obsega mnogo večji delež poseljenih območij in s tem tudi stavb. Pomembna naloga, ki v okviru DTK 5 sistemsko še ni urejena, je posodabljanje topografskih podatkov. Raziskave v svetu so usmerjene v razvoj polsamodejnih in samodejnih postopkov za vzdrževanje in zajem topografskih podatkov z integracijo različnih vrst podatkov, od letalskih in satelitskih posnetkov, bližnjeslikovnih posnetkov, podatkov aero- in terestričnega laserskega skeniranja in radarskih podob. Pregled samodejnih postopkov za odkrivanje topografskih objektov, ki temelji na kombinaciji podatkov iz različnih virov, pridobljenih med letoma 2004 in 2008, so zbrali Mayer, Hinz in Stilla (2008). Kljub napredku v razvoju samodejnih postopkov za zajem topografskih podatkov teoretično razvite metode še vedno niso zaživele v praksi (Mayer, 2008). Oprijemljivejši rezultati so bili pridobljeni z raziskavami sistemov, v katerih se skuša s polsamodejnimi ali samodejnimi postopki zgolj odkriti neskladja med obstoječo podatkovno bazo in novimi viri. Ugotovljeno spremembo potem obravnava operater, ki sprejme končno odločitev in po potrebi zajame podatke $\mathrm{v}$ topografsko bazo. Takšen postopek lahko prihrani veliko časa $\mathrm{v}$ primerjavi s klasičnim iskanjem sprememb (Holland in sod., 2008), ki najpogosteje poteka z vizualno primerjavo topografskih podatkov z letalskimi posnetki ali ortofotom. Organizacija EuroSDR je izvedla obsežno raziskavo samodejnega iskanja sprememb med stavbami $\mathrm{v}$ 2D-topografskih bazah. Ugotovili so, da ima tak postopek znaten ekonomski učinek, saj izloči med $80 \%$ in $90 \%$ stavb v bazi, ki jih operaterju ni treba pregledati (Champion, 2009). Tovrstni postopki so uporabni tudi za kontrolo zajema podatkov v topografsko bazo.

Za iskanje sprememb v topografski bazi se v glavnem uporabljata dve vrsti postopkov: primerjava podatkov, ki so pridobljeni iz ene vrste senzorjev v dveh različnih časovnih obdobjih, ali primerjava podatkov obstoječe podatkovne baze z rezultati novega zajema (Vosselman in ostali, 2004). V naši raziskavi smo se posvetili drugi možnosti. Predvsem nas je zanimala uporaba alternativnih virov za zajem podatkov v topografsko bazo. Analizirali smo, kakšno natančnost lahko dosežemo, za katera merila oziroma ravni podrobnosti je metoda uporabna tudi za zajem podatkov v bazo ter, končno, kako so podatki samodejnega zajema uporabni za iskanje sprememb v topografski bazi.

V raziskavi smo se posvetili samodejnemu zajemu stavb. V Sloveniji vodimo podatke o stavbah v bazi DTK 5 in katastru stavb (KS). Kot podatkovni vir za iskanje sprememb v obstoječih bazah smo uporabili podatke laserskega skeniranja ter barvni in bližnje infrardeči ortofoto. Oblak točk, ki ga skupaj z atributnimi podatki pridobimo z laserskim skeniranjem, že sam omogoča uporabo raznih metod za samodejni zajem stavb (npr. Dorninger, Pfeifer, 2008; Pfeifer in sod., 
2007; Hofmann, Mass, Streilein, 2002; Vosselman, Dijkman, 2001) ali pa podatke laserskega skeniranja kombiniramo z drugimi podatkovnimi viri, najbolj pogosto so to multispektralne podobe (Rottensteiner in ostali, 2007; Sohn in Dowman, 2007). Obdelava osnovnih podatkov laserskega skeniranja zahteva posebno programsko opremo, ki je pogosto nimamo. Zato smo uporabili izvedene podatke laserskega skeniranja: digitalni model površja (DMP) in digitalni model reliefa (DMR), oba v rastrskem zapisu in s prostorsko ločljivostjo $0,5 \mathrm{~m}$. Poudarek je tako na uporabi izvedenih podatkov laserskega skeniranja, kjer nimamo podatkov o različnih odbojih, ampak obravnavamo le končna izdelka. Metoda je zato uporabna tudi, ko imamo na razpolago natančen DMP, pridobljen iz drugačnega vira (npr. fotogrametrični zajem; Demir in Baltsavias, 2007; Lu in ostali, 2006). Dosedanje raziskave opisujejo tudi kombinacijo višinskih podatkov in multispektralnih posnetkov za iskanje sprememb v topografski bazi (Champion in ostali, 2008; Matikainen in ostali, 2010; Rottensteiner, 2008). V članku je povzet del postopkov za samodejni zajem stavb, ki so bili razviti v okviru doktorske disertacije (Grigillo, 2010).

\section{2 ŠTUDIJSKO OBMOČJE IN OPIS PODATKOV}

Predlagani pristop smo preizkusili na mestnem obrobju Ljubljane. Kot obstoječe podatke smo uporabili podatke katastra stavb (KS), kot vir za evidentiranje sprememb pa podatke lidarskega snemanja, ki je bilo izvedeno v letu 2007 na južnem delu Ljubljane in Ljubljanskem barju, ter državni ortofoto. KS in ortofoto smo pridobili na Geodetski upravi Republike Slovenije.

Podatke laserskega skeniranja predstavljata DMP in DMR, oba v rastrskem zapisu in s prostorsko ločljivostjo $0,5 \mathrm{~m}$. Izvornih lidarskih podatkov (oblakov točk z atributi) nismo imeli. Uporabljene slikovne podatke sestavljata državni barvni ortofoto DOF050 s prostorsko ločljivostjo $0,5 \mathrm{~m}$ in državni bližnje infrardeči ortofoto DOF100IR s prostorsko ločljivostjo $1 \mathrm{~m}$. Oba ortofota sta bila izdelana leta 2006 iz posnetkov CAS in zapisana $\mathrm{v}$ barvnem prostoru RGB z radiometrično ločljivostjo 24 bitov (po 8 bitov za rdeči, zeleni in modri sloj). DOF100IR smo z uporabo DOF050, pretvorjenega v sivo barvno lestvico, izostrili na prostorsko ločljivost $0,5 \mathrm{~m}$.

Ožje območje preizkušanja metod za zajem stavb ima površino $500 \mathrm{~m} \times 350 \mathrm{~m}$ z robnimi koordinatami v državnem koordinatnem sistemu D48/GK:

$$
\text { Y: } 460.725 \text { m - 461.225 m; } \quad \text { X: } 99.200 m-99.550 m \text {. }
$$

Rezultate samodejnega iskanja in zajema stavb smo primerjali z grafičnim delom KS in dejanskim stanjem v naravi, ki smo ga pridobili s primerjavo oblike stavb na ortofotu, DMP in KS ter s terenskim ogledom.

\section{METODOLOGIJA}

Glavne stopnje samodejnega zajema stavb prikazuje slika 1. Postopek lahko strnemo v naslednje korake:

- izračun nDMP iz DMP in DMR ter izdelava maske visokih objektov v nDMP,

- izdelava začetne maske stavb z izločitvijo vegetacije iz maske visokih objektov v nDMP, ki vključuje izračun modificiranega vegetacijskega indeksa in indeksa senc iz multispektralnega 
ortofota ter izboljšavo indeksa senc z upoštevanjem njegove homogenosti,

- izdelava maske za test površin stavb, maske stavb v nDMP in rastrskih obrisov stavb,

- vektorski zajem stavb iz rastrskih obrisov stavb z vključitvijo maske za test površin stavb.

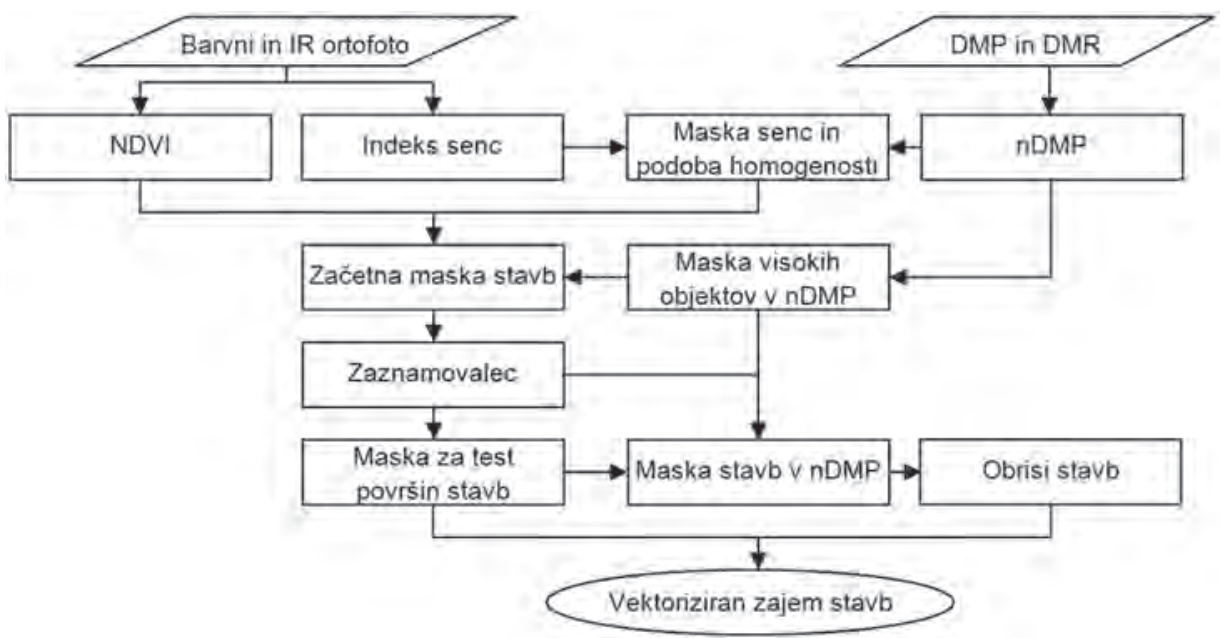

Slika 1: Diagram poteka zajema stavbizDMP in ortofota

Za potrebe iskanja sprememb v topografski bazi smo vektorske podatke samodejnega zajema in KS rasterizirali. Iskanje sprememb smo izvedli samodejno s primerjavo binarnih podob samodejnega zajema, KS in dejanskega stanja v naravi.

\subsection{Izračun nDMP}

Razlika med DMP in DMR predstavlja normaliziran digitalni model površja (nDMP). Na njem so vključeni le objekti, ki segajo nad zemeljsko površino. Iz nDMP izdelamo masko, ki vključuje le območja, pri katerih je možnost, da so na njih stavbe. Pri izdelavi maske smo uporabili prag 2 $\mathrm{m}$, saj se glede na operativno navodilo za zajem podatkov o stavbah $\mathrm{v}$ topografskih bazah vodijo le stavbe, ki so višje od dveh metrov (GURS, 2001). Slika 2 prikazuje DMR (a), DMP (b) in masko visokih objektov v nDMP (c). Maska poleg stavb vsebuje še druge objekte, višje od dveh metrov. To je $v$ glavnem vegetacija. 


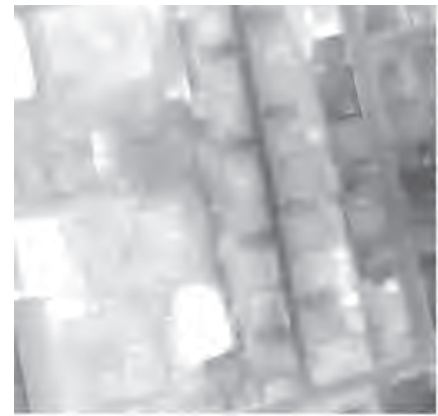

(a)

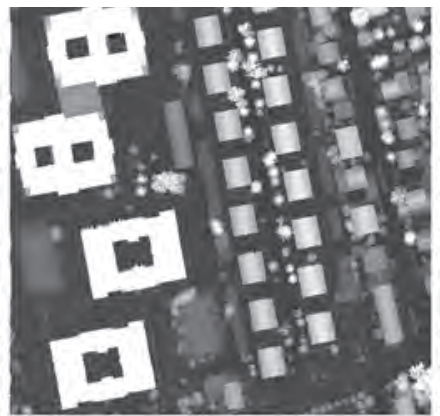

(b)

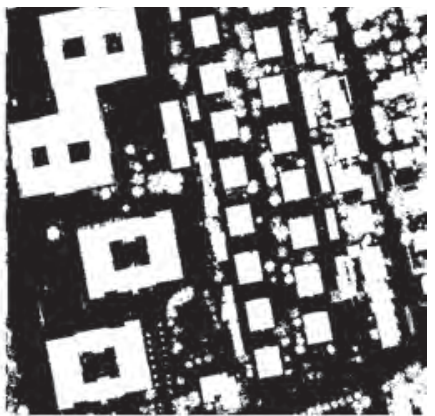

(c)

Slika 2: Višinski podatki in začetna maska stavb: DMR (a), DMP (b) in maska visokih objektov v nDMP (c).

\subsection{Modificiran vegetacijski indeks in indeks senc}

Maska visokih objektov, izdelana iz nDMP, še vedno vsebuje vegetacijo, ki sega vsaj dva metra nad površino tal (drevesa). Vegetacijo odstranimo iz maske z uporabo vegetacijskega indeksa, ki ga običajno izračunamo iz rdečega in bližnjega infrardečega kanala. Ortofoto ne vsebuje izvornega rdečega in infrardečega kanala, zato smo v raziskavi uporabili svojo metodo za izračun vegetacijskega indeksa, ki temelji na uporabi bližnjega infrardečega ortofota, zapisanega $\mathrm{v}$ barvnem prostoru RGB, in popravi vegetacijskega indeksa $\mathrm{z}$ indeksom senc ter analizo teksture.

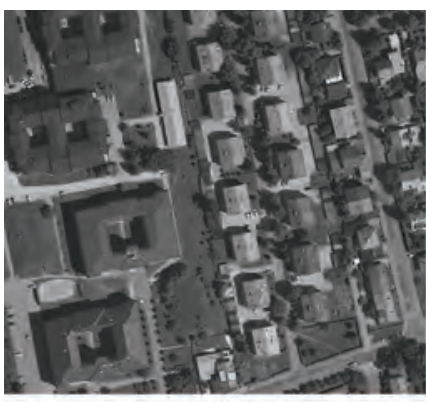

(a)

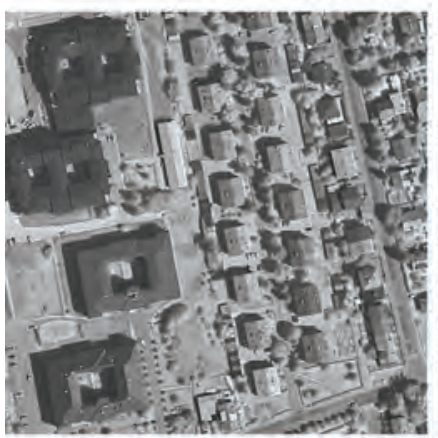

(d)

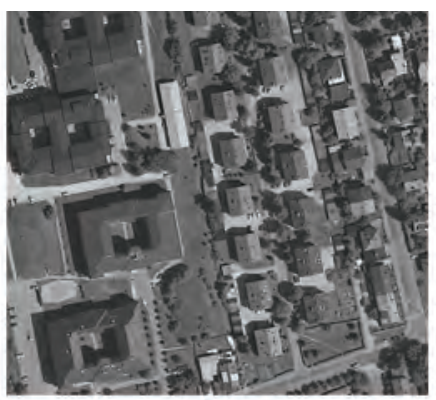

(b)

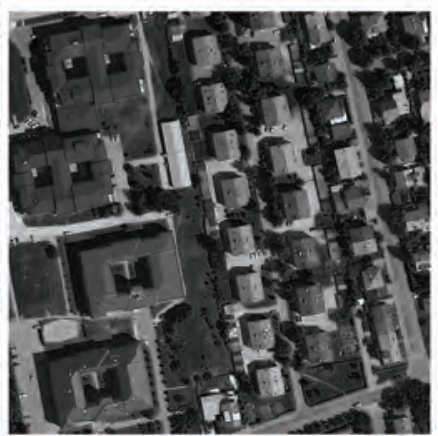

(e)

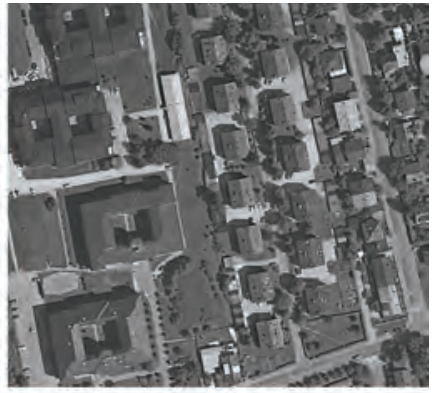

(c)

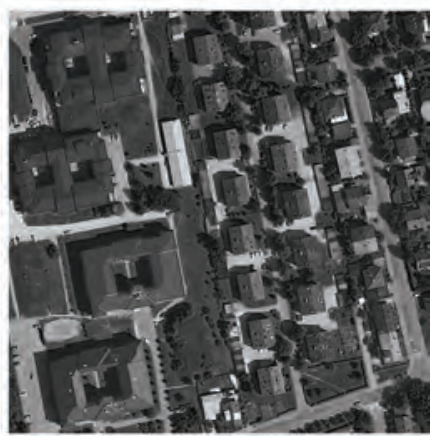

(f)

Slika 3: Rdeči, zeleni in modri sloj barvnega ortofota DOF050 (a-c) in izostrenega bližnjega infrardečega ortofota DOF100IR (d-f)

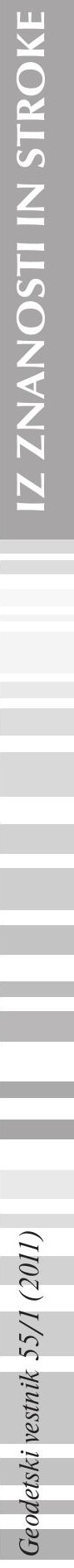


Slika 3 v zgornji vrsti prikazuje rdeč (a), zelen (b) in moder (c) sloj DOF050. Ustrezni sloji DOF100IR so prikazani v spodnji vrsti (slika $3 \mathrm{~d}-\mathrm{f}$ ). Z vizualno interpretacijo vseh slojev ugotovimo, da ima vegetacija najvišje vrednosti tonov na rdečem sloju DOF100IR (d) in najnižje vrednosti tonov na zelenem sloju DOF100IR (e). Ta dva zato uporabimo za izračun normaliziranega diferencialnega vegetacijskega indeksa ( NDVI) (1):

$$
\mathrm{NDVI}=\frac{\mathrm{IR}-\mathrm{R}}{\mathrm{IR}+\mathrm{R}}
$$

v katerem kot kanal R uporabimo zeleni sloj DOF100IR, kot kanal IR pa rdeči sloj DOF100IR, oba izostrena na prostorsko ločljivost $0,5 \mathrm{~m}$. Ker v enačbi (1) nismo uporabili klasičnih kanalov za izračun NDVI (rdeč in bližnje infrardeč kanal), lahko govorimo o modificiranem vegetacijskem indeksu NDVI.

V primerjavi z zelenim slojem imajo na rdečem sloju poleg vegetacije višje vrednosti tonov tudi sence. Modificiran NDVI jih zato razvrsti kot vegetacijo. Uporaba modificiranega NDVI za izločanje vegetacije iz nadaljnje obdelave podatkov tako povzroči nevarnost, da iz obdelave izpadejo osenčeni deli stavb. Pred nadaljnjim postopkom moramo zato odkriti sence, ki se pojavljajo na stavbah.

Sence na podobah prepoznamo z izračunom indeksa senc (SI). Ono in sod. (2007) predlagajo popravo vegetacijskega indeksa $\mathrm{z}$ normalizacijo kanalov v obdelavi z njihovimi aritmetičnimi sredinami. Izračun normaliziranih vrednosti kanalov $R_{d}$ je podan $\mathrm{z}$ enačbo (2):

$$
R_{d}^{(i)}=\frac{r_{d}^{(i)}}{\frac{1}{N} \sum_{j=1}^{N} r_{d}^{(j)}},
$$

kjer predstavljajo $r_{d}$ izvoren odboj, $i$ je oznaka kanala in $N$ število kanalov v obdelavi. Za izračun normaliziranih kanalov smo uporabili vseh šest slojev ortofota. SI pridobimo z razliko med normaliziranim in izvornim kanalom (Ono in sod., 2007). Za izračun SI uporabimo izostren rdeči sloj DOF100IR (3):

$$
\mathrm{SI}=R_{d}^{r I R}-r_{d}^{r I R},
$$

Pred izračunom SI smo iz normaliziranega kanala $R_{d}^{r I R}$ odstranili šum s filtrom mediana velikosti $3 \times 3$ pikslov.

Izdelavo začetne maske stavb in popravo vegetacijskega indeksa zaradi senc izvedemo v nekaj skupnih korakih. Z modificiranim NDVI izdelamo masko območja, ki ne vsebuje vegetacije (za prag smo uporabili empirično vrednost 0,36 ). S konjunkcijo maske, ki izključuje vegetacijo in maske visokih objektov, v nDMP izdelamo masko stavb, ki ne vsebuje osenčenih delov stavb. To masko v nadaljevanju dopolnimo. Najprej izračunamo indeks senc (SI) in iz njega izdelamo masko senc. Za masko senc smo uporabili empirično določen prag 0,08. S konjunkcijo maske senc in maske visokih objektov $\mathrm{v}$ nDMP dobimo sence na območjih, ki segajo nad površino tal (stavbe, vegetacija idr.). Sence, ki ne ležijo na stavbah, izločimo z analizo teksture, saj ima vegetacija na nDMP bolj grobo teksturo od osenčenih streh. Za ločevanje senc na stavbah in vegetaciji izračunamo podobo homogenosti, ki je ena od mer za teksturo. Homogenost $f$ 
pridobimo iz matrike relativnih frekvenc $P(i, j)$, ki izraža pojavnost dveh sosednjih pikslov na podobi ali delu podobe, enega $\mathrm{z}$ intenziteto $i$ in drugega $\mathrm{z}$ intenziteto $j$ (Haralick in sod., 1973). Homogenost izračunamo (4):

$$
f=\sum_{i=1}^{N_{g}} \sum_{j=1}^{N_{g}}\left(\frac{P(i, j)}{R}\right)^{2},
$$

kjer je $N_{g}$ zaloga intenzitet v podobi, $R$ je konstanta, s katero normaliziramo podobo. Za izračun smo uporabili filter velikosti $3 \times 3$ pikslov. Kot kandidate za stavbe smo obdržali območja s homogenostjo, višjo ali enako 0,9 , obenem smo odstranili površine, ki so merile manj kot $2 \mathrm{~m}^{2}$,

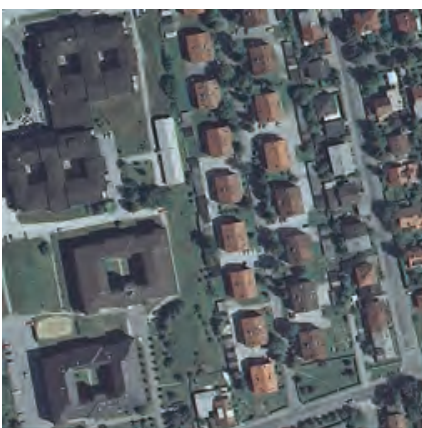

(a)

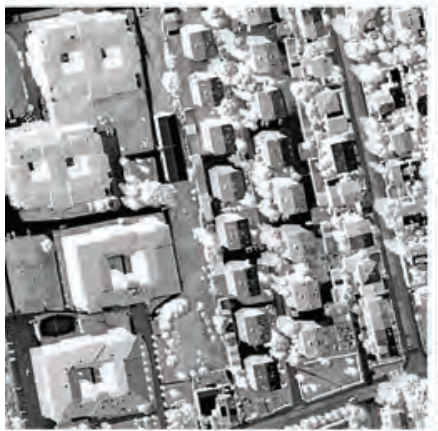

(d)

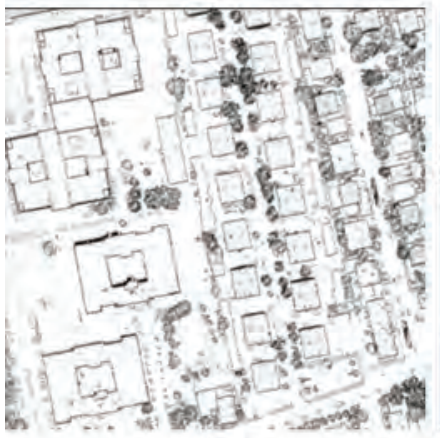

(g)

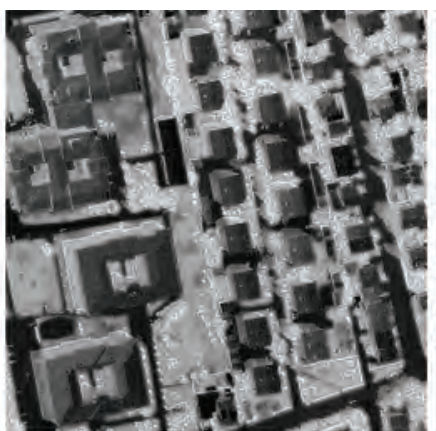

(b)

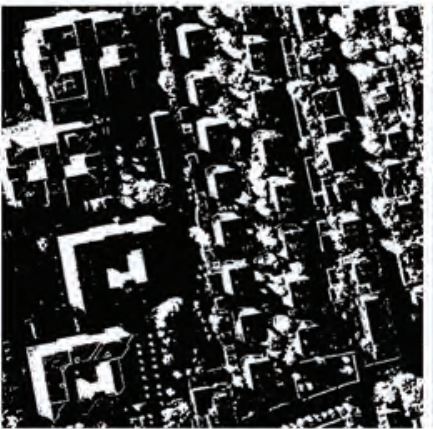

(e)

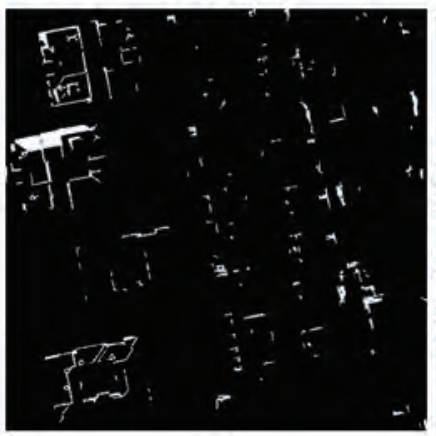

(h)

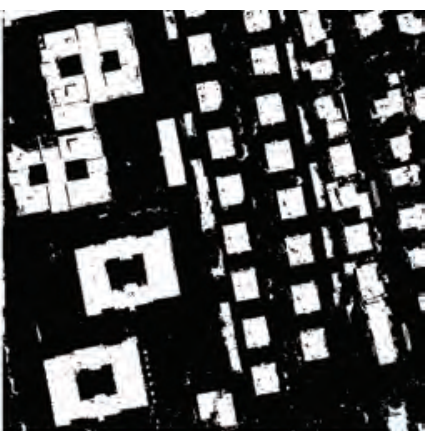

(c)

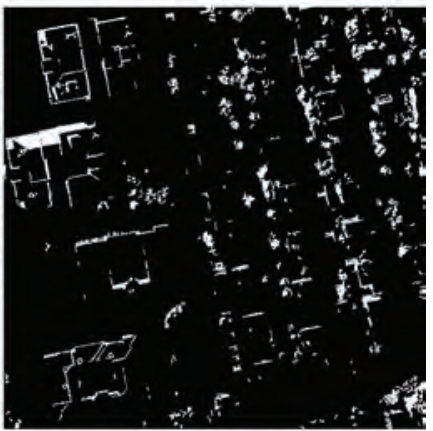

(f)

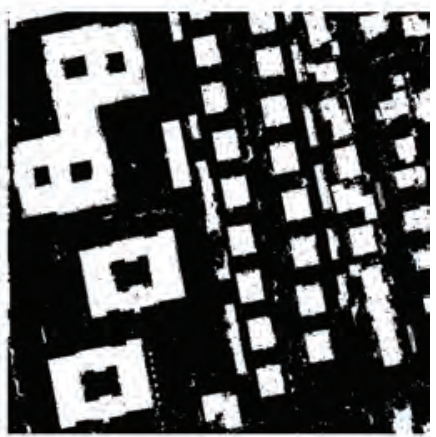

(i)

Slika 4: Izdelava začetne maske stavb

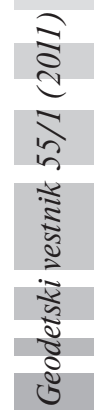


ter z morfološkim zapiranjem s strukturnim elementom »disk « (Matlab, 2010) velikosti 4 pikslov zabrisali robove stavb. V nadaljevanju smo masko stavb dopolnili s sencami, ki imajo na maski visokih objektov v nDMP vrednost 1 in imajo veliko homogenost $(\geq 0,9)$.

Slika 4 prikazuje potek izdelave začetne maske stavb. V zgornji vrsti so prikazani barvni ortofoto za predstavitev območja (a), NDVI (b) in maska stavb, ki ne vključuje osenčenih delov stavb (c). Srednja vrsta prikazuje SI (d) (kontrast je za prikaz izboljšan z linearnim raztegom histograma $\mathrm{z}$ nasičenjem 2,5 \%), masko senc (e) in konjunkcijo maske senc $\mathrm{z}$ masko visokih objektov $\mathrm{v}$ nDMP (f). Zadnja vrsta prikazuje podobo homogenosti (g), območja, s katerimi dopolnimo masko stavb (h) (izločena osenčena vegetacija), in začetno masko stavb (i).

\subsection{Nadaljnje obdelave mask}

Za končen zajem stavb bomo potrebovali masko za testiranje površin stavb in obrise stavb, izdelane iz maske visokih objektov v nDMP. Maska za test površin stavb vsebuje samo stavbe na testnem območju. Izdelamo jo z vrsto morfoloških operacij iz začetne maske stavb, predstavljene na sliki 4(i). Ta še vedno vsebuje nekatere nepravilnosti zaradi raznih objektov, ki so višji od dveh metrov in ne pomenijo stavb (ograje, tovornjaki), šuma v DMP, napak v izračunu vegetacijskega indeksa in SI. Začetno masko stavb najprej popravimo, tako da v njej zapolnimo luknje. Paziti moramo, da pri tem ne zapolnimo lukenj, ki pomenijo interjerje stavb (odstranili smo luknje s površino, manjšo od $3 \mathrm{~m}^{2}$ ). Iz začetne maske stavb nato odstranimo objekte, ki so tanjši od 1,5 m. Postopek opravimo z morfološkim odpiranjem s strukturnimi elementi z obliko -, |, / in $\backslash \mathrm{z}$ razsežnostjo treh pikslov. Iz maske odstranimo še objekte, ki imajo manjšo površino od $4 \mathrm{~m}^{2}$ (glede na operativno navodilo za zajem podatkov o stavbah se v topografskih bazah vodijo le stavbe, katerih površina je večja od 4 m²; GURS, 2001). Tako dobimo masko, na kateri so zanesljivo le stavbe, ki imajo zaradi številnih morfoloških operacij pokvarjeno obliko. Dobljeno masko zato uporabimo le kot zaznamovalec v operaciji morfološkega odpiranja z rekonstrukcijo, s katero obdelamo začetno masko stavb, na kateri smo zapolnili manjše luknje. Z morfološkim odpiranjem z rekonstrukcijo iz podobe odstranimo neželene objekte, pri čemer objekti, ki jih označuje zaznamovalec, obdržijo prvotno obliko (Gonzales in sod., 2004).

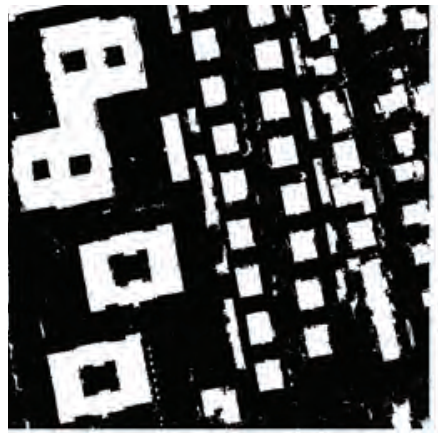

(a)

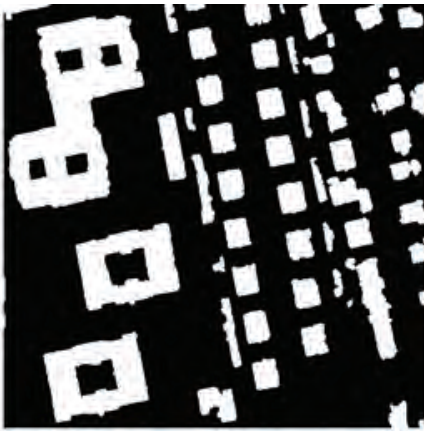

(b)

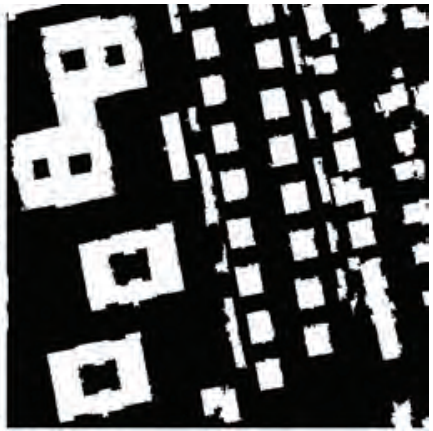

(c)

Slika 5: Maska stavb (a), zaznamovalec (b) in maska za test površin stavb (c) 
Slika 5 prikazuje začetno masko stavb z zapolnjenimi luknjami (a), zaznamovalec, ki vsebuje le stavbe (b), in rekonstruirano masko stavb, ki smo jo poimenovali maska za test površin stavb (c). Nepravilne oblike stavb na končni maski (c) so v glavnem posledica visoke vegetacije, ki prekriva nekatere strehe, šuma $\mathrm{v}$ podatkih $\mathrm{nDMP}$ in manjših pogreškov $\mathrm{v}$ predhodni obdelavi. Napake niso moteče, saj bo tako pridobljena maska uporabljena le za test površin pri zajemu stavb (opis v 3.4) in nadaljnjo pripravo maske nDMP za končni zajem stavb.

Drug vhodni podatek v zajem stavb so obrisi stavb, izdelani iz maske visokih objektov v nDMP, ki jo prikazuje slika 2(c). Za izdelavo obrisov stavb potrebujemo masko visokih objektov $\mathrm{v}$ nDMP, na kateri en objekt na maski pomeni eno stavbo oziroma več stavb, če se te v prostoru dotikajo. Masko visokih objektov v nDMP zato dodatno obdelamo. V prvem koraku ločimo med seboj objekte $\mathrm{v}$ maski, ki so povezani le $\mathrm{z}$ enim pikslom, in masko odpremo z rekonstrukcijo $\mathrm{z}$ že omenjenim zaznamovalcem stavb. Preostale stavbe na maski ločimo z masko za test površin stavb, ki jo zaradi tega še dodatno obdelamo: nepravilnosti na zunanjih obrisih stavb zabrišemo z morfološko erozijo s strukturnim elementom »diamond, 1«(Matlab, 2010), ponovno odstranimo objekte in luknje s površino pod $4 \mathrm{~m}^{2}$, zapremo vsak objekt posebej s kvadratom razsežnosti $3 \times 3$ pikslov (zapiranje vsakega objekta posebej je pomembno, sicer bi združili objekte, ki so zelo blizu skupaj) in razširimo objekte za $2 \mathrm{~m}$ v vse strani (le če to ne povzroči združevanja objektov). $\mathrm{S}$ konjunkcijo tako dobljene maske stavb in maske visokih objektov v nDMP dobimo masko stavb v nDMP, kjer so stavbe med seboj ločene. Na maski stavb v nDMP zbrišemo objekte, ki se dotikajo stranic območja, odstranimo objekte in luknje, manjše od $4 \mathrm{~m}^{2}$, in izdelamo zunanje obrise objektov. Ti obrisi so glavni vhodni podatek za končni zajem stavb.

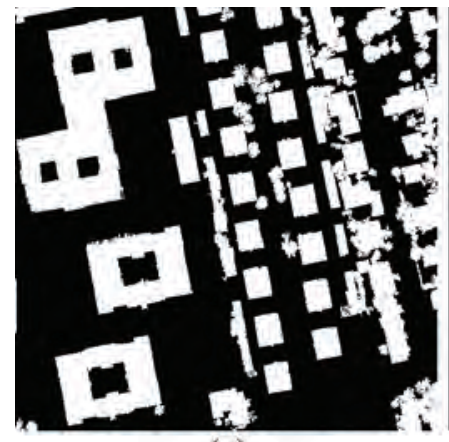

(a)

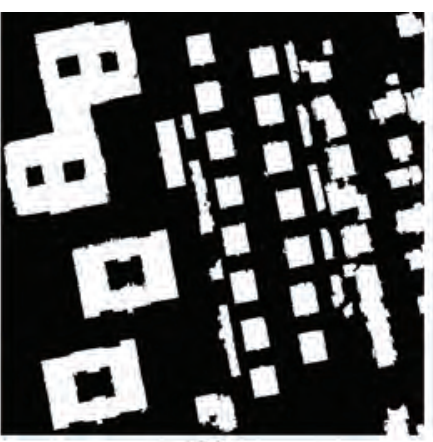

(b)

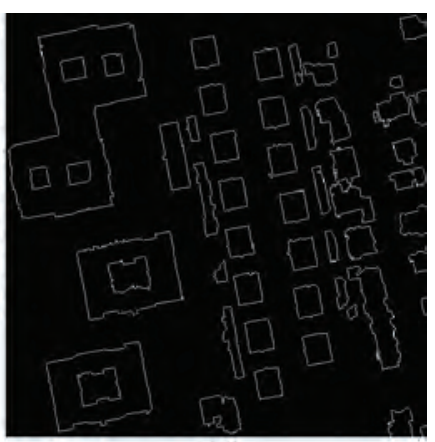

(c)

Slika 6: Izdelava rastrskih obrisov stavb

Slika 6 prikazuje rekonstruirano masko visokih objektov v nDMP (a), masko stavb v nDMP (b) in rastrske obrise stavb (c).

\subsection{Zajem stavb}

Končni zajem stavb izvedemo na izdelanih obrisih stavb, pridobljenih iz nDMP. V postopek vključimo še masko za test površin stavb. Podoba obrisov je rastrska, obrisi niso predstavljeni z ravnimi linijami, kot jih pričakujemo pri stavbah, koti med linijami obrisa niso pravi koti. Končne 
obrise stavb zato vektoriziramo z uporabo transformacije Radon. Transformacija Radon je vsota pravokotnih projekcij intenzitet podobe na radialno premico, usmerjeno pod določenim kotom in z izhodiščem smeri v sredini podobe (Matlab, 2010). Z njo poiščemo premice, vzdolž katerih se raztezajo stavbe na podobi obrisov. V zajemu obravnavamo vsak obris posebej.

\section{Potek zajema:}

- iskanje orientacije oziroma glavne osi stavbe. S transformacijo Radon poiščemo os, vzdolž katere se razteza stavba (največja vrednost $v$ matriki transformacije Radon). Iskanje izvedemo $\mathrm{v}$ smereh od $0^{\circ}$ do $180^{\circ} \mathrm{s}$ korakom pol stopinje. Ker so linije obrisa nepravilne, za vsako stavbo

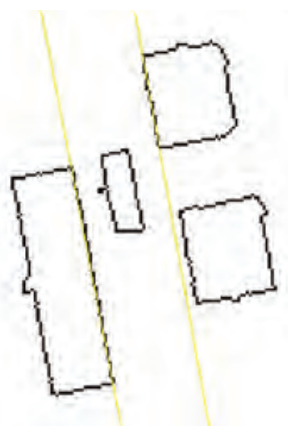

(a)

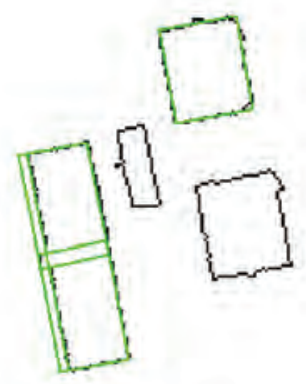

(d)

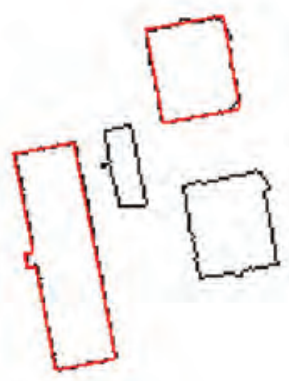

(g)

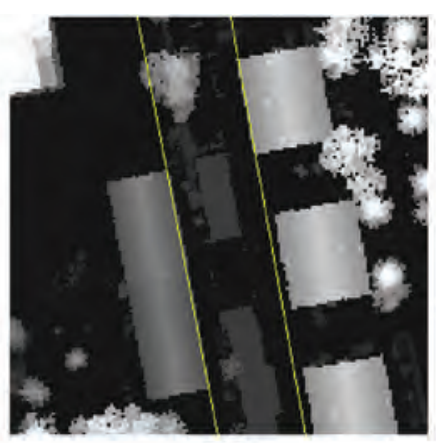

(b)

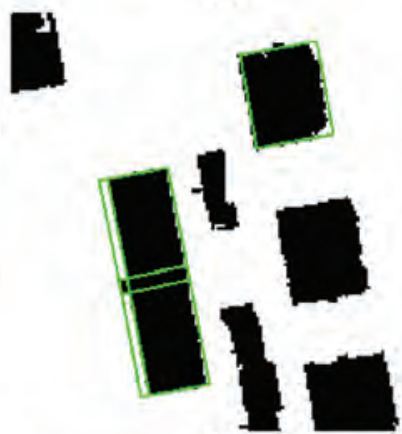

(e)

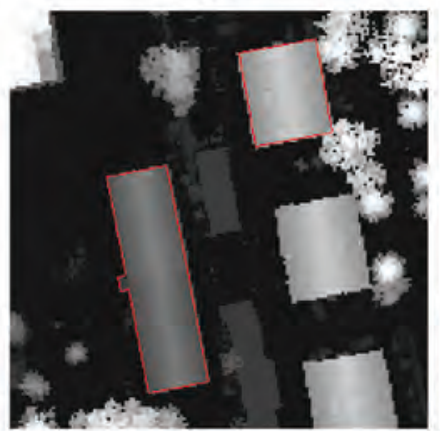

(h)

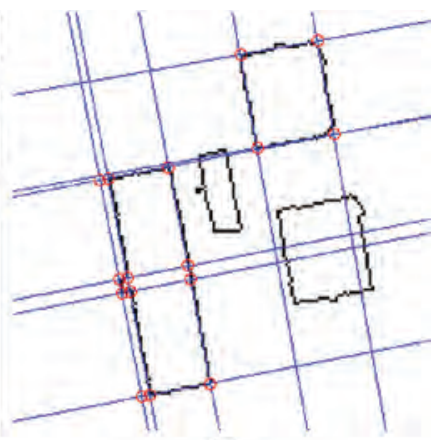

(c)

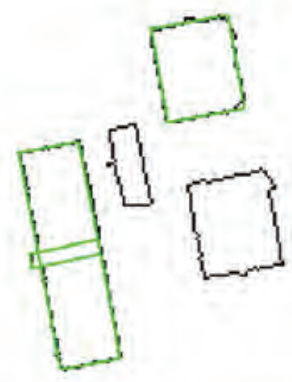

(f)

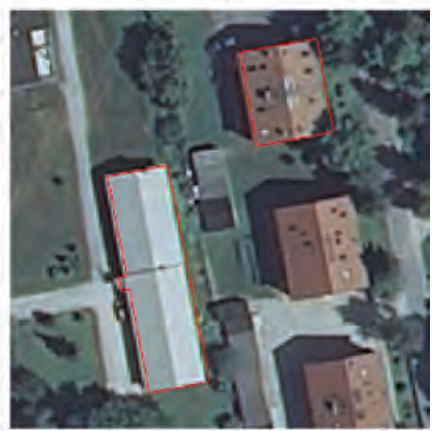

(i) 
poiščemo dve smeri osi. Če se smeri med seboj razlikujeta, obdržimo tisto, ki je bližja smerem osi sosednjih objektov;

- iskanje vseh premic, ki so vzporedne glavni osi stavbe in opisujejo obris stavbe. Premice iščemo, dokler je največja vrednost v matriki transformacije Radon $R_{\max }$ večja ali enaka 3,25, oziroma poiščemo vsaj dve vzporedni premici. Parameter 3,25 pomeni, da na premici verjetno ležijo vsaj 3 piksli, ki označujejo obris stavbe. Premice iščemo na medsebojni oddaljenosti $0,5 \mathrm{~m}$, kar v našem primeru predstavlja velikost enega piksla;

- ker predvidevamo, da imajo stavbe pravokotne stranice, enako poiščemo še vse pravokotne premice, ki opisujejo obris stavbe. Pogoj za prenehanje iskanja premic vzdolž osi, ki je pravokotna na glavno os stavbe, nekoliko omilimo $\left(R_{\max } \geq 2,75\right.$ oziroma poiščemo vsaj dve pravokotni premici);

- poiščemo presečišča med seboj pravokotnih premic in iz njih izdelamo pravokotnike;

- vsi pravokotniki ne opisujejo stavbe, zato vsakega testiramo. Če je razmerje med površino, ki jo tvori presek pravokotnika z masko za test površin stavb, in površino, izračunano iz oglišč pravokotnika, večje od 0,6, pravokotnik obdržimo, sicer ga zavržemo. Pri obravnavanju interjerjev stavb je test površine izveden z negacijo maske za test površin stavb;

- končni obris stavbe oziroma njenega interjerja izdelamo s polilinijo, ki orisuje obod obdržanih pravokotnikov.

Zajem stavb opisuje slika 7. Za predstavitev sta izbrani le dve stavbi. Zgornja vrsta prikazuje glavno os stavbe na rastrskem obrisu stavbe (a), glavno os stavbe na nDMP (b) in najdene premice, ki opisujejo obris stavbe ter njihova presečišča (c). Srednja vrsta prikazuje izdelane pravokotnike na rastrskem obrisu stavb (d), iste pravokotnike na maski za test površin (e) in obdržane pravokotnike na obrisu stavb (f). Zadnja vrsta na sliki 7 prikazuje rezultate zajema stavb: na obrisu stavb (g), na nDMP (h) in na barvnem ortofotu DOF050 (i). Obrisi stavb so na barvnem ortofotu videti nekoliko premaknjeni. Dejansko so premaknjene strehe stavb na ortofotu. Premik je posledica izdelave ortofota $\mathrm{z}$ uporabo DMR, ki opisuje zgolj zemeljsko površje in ne vključuje stavb (Kraus, 2007). Slike 7(a, c, d, e, f in g) so predstavljene z negativi.

\subsection{Iskanje sprememb}

Za iskanje sprememb rezultat samodejnega vektorskega zajema stavb in KS rasteriziramo. Iskanje sprememb poteka samodejno s primerjavo objektov (stavb) na binarnih podobah zajema in KS. S konjunkcijo med KS in samodejnim zajemom odkrijemo stavbe, ki so v KS in jih je samodejni postopek našel. Z operatorjem »izključujoči ALI« med stavbami v KS in omenjeno konjunkcijo ugotovimo, katerih stavb, ki so v bazi, nam ni uspelo poiskati oziroma na terenu ne obstajajo več. Z operatorjem izključujoči ALI, ki ga izvedemo med rezultati zajema in omenjeno konjunkcijo, poiščemo nove stavbe, ki jih še ni v bazi. Za preostale spremembe primerjamo objekte na konjunkciji. Objekte razdelimo na štiri razrede glede na razmerje površin, ki jih imajo na binarnih podobah KS in samodejnega zajema:

- manj kot 10 \% površine objekta na KS prekriva objekt na zajemu => porušena/neodkrita stavba; 
- manj kot 10 \% površine objekta na zajemu prekriva objekt na KS => nova stavba;

- objekt KS prekriva od 10 \% do P površine objekta na samodejnem zajemu => nov prizidek;

- nad P objekta na KS prekriva objekt na samodejnem zajemu => odkrita stara stavba.

P predstavlja izbran prag. V našem primeru smo uporabili $\mathrm{P}=70 \%$. Matikainen in ostali (2004) predlagajo izbiro praga $80 \%$ za industrijske predele, $70 \%$ za območja z večjimi stanovanjskimi objekti in 60 \% za območja z manjšimi družinskimi hišami. V program smo vključili tudi možnost, da nas opozori na spremembo, kadar več objektov na KS prekriva en objekt samodejnega zajema. Tako smo pravilno našli večino prizidkov stavb.

Oceno učinkovitosti samodejnega iskanja sprememb ovrednotimo s primerjavo dejanskega stanja na terenu, topografske baze, ki jo posodabljamo (v našem primeru KS), in rezultati samodejnega zajema. Ocenili smo popolnost in pravilnost postopka (Heipke in ostali, 1997) (5):

$$
\begin{aligned}
& \text { popolnost }=\frac{R P}{R P+L N} ; \\
& \text { pravilnost }=\frac{R P}{R P+L P} .
\end{aligned}
$$

Popolnost opisuje delež dejanskih sprememb, ki jih samodejni postopek zazna. Pravilnost opisuje delež zaznanih sprememb, ki ustrezajo dejanskim spremembam. $R P$ je število objektov (stavb), ki jih samodejni postopek označi kot spremembo in so dejansko spremenjeni. $L N$ je število objektov, ki jih samodejni postopek ne prepozna kot spremembo, a so se spremenili. $L P$ je število objektov, ki jih samodejni postopek označi kot spremembo, a se dejansko niso spremenili.

\section{REZULTATI IN RAZPRAVA}

Po nastavitvi pragov za izračun mask iz raznih indeksov poteka zajem stavb povsem samodejno. Razen podobe, ki opisuje homogenost območja, smo vse druge korake sprogramirali v programu Matlab. Podobo homogenosti smo izdelali v programu ENVI. Ta podoba je v kombinaciji z indeksom senc izvorni korak v postopku, s katerim smo izboljšali masko stavb. Slika 8 prikazuje rezultate zajema stavb v primerjavi z nDMP (a) in barvnim ortofotom DOF050 (b).

Rezultate samodejnega zajema smo primerjali s podatki aktualnega KS in dejanskim stanjem na terenu. Referenčno karto dejanskega stanja smo izdelali z ročno popravo KS na podlagi DOF050, DMP in terenskega ogleda. Slika 9 prikazuje prekritje samodejnega zajema (rdeča barva) in KS (modra barva) (a) ter prekritje KS in DOF050 (b). Pomembno je poudariti, da je bil KS za to območje izdelan s terestričnimi meritvami. Pri teh je bil obod stavb določen z meritvami temeljev, kar se razlikuje od fotogrametričnega zajema, pri katerem zajemamo obode streh. Zaradi tega imajo stavbe v KS manjšo površino.

V analizi rezultatov smo se posvetili dvema vprašanjema: koliko in za katera merila je postopek opisanega samodejnega zajema primeren za zajem podatkov v topografsko bazo in kakšna je primernost opisane metode za iskanje sprememb v podatkovni bazi. 


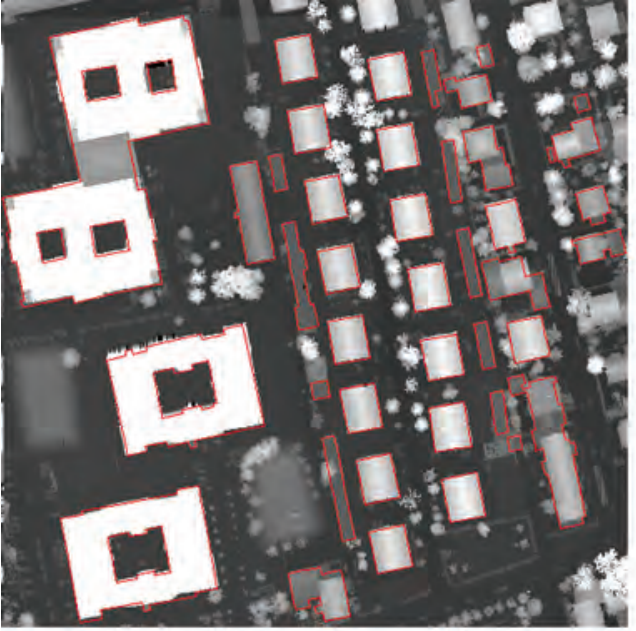

(a)

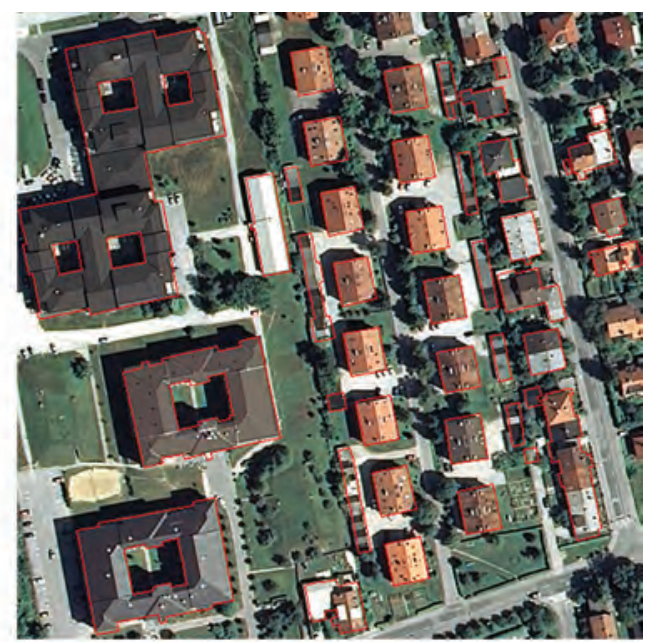

(b)

Slika 8: Rezultati zajema stavb, prikazani na nDMP in DOF050.

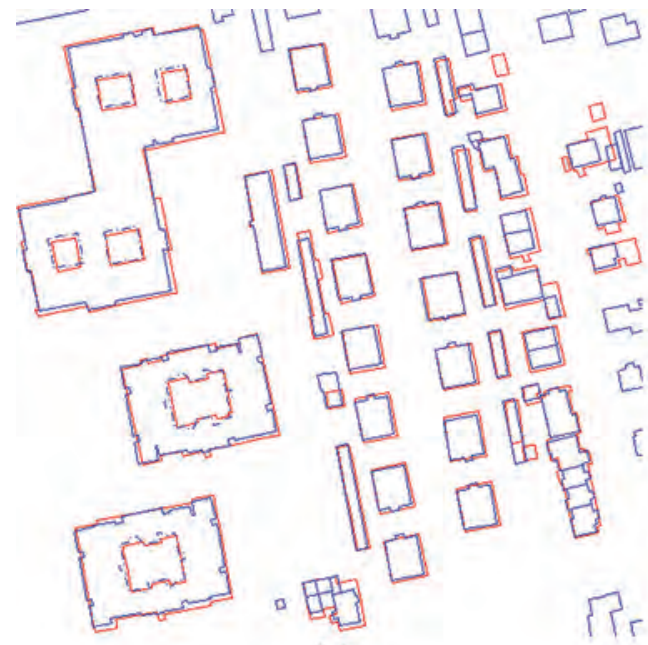

(a)

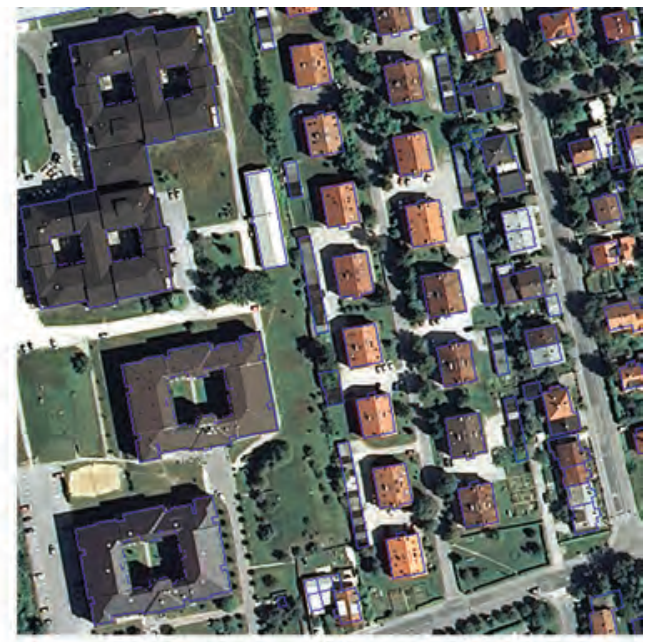

(b)

Slika 9: Primerjava rezultatov zajema stavb s KS

Na obravnavanem območju je 107 stavb (stavbe, ki se v prostoru stikajo, smo šteli kot eno stavbo). S samodejnim postopkom smo našli 101 stavbo oziroma 94,4 \% vseh stavb na območju. Šest stavb samodejni postopek ni zaznal, in sicer so bile to stavbe z manjšo površino. Dve smo nehote odstranili v postopku morfološkega odpiranja z rekonstrukcijo, štirih pa samodejni postopek ni odkril, ker jih v naravi skoraj v celoti prekrivajo drevesa (tri vrtne lope in ena lesena garaža). Samodejni postopek je našel šest stavb, ki dejansko ne obstajajo v naravi. Vse so imele manjšo površino in so se pojavile na asfaltnih površinah ali na robovih dreves. Preglednica 1 prikazuje oceno samodejnega iskanja stavb. 


\begin{tabular}{|l|c|c|}
\hline & Stevilo & $\%$ \\
\hline Vse stavbe na območju & 107 & 100 \\
\hline Najdene stavbe & 101 & 94,4 \\
\hline Neobstoječe stavbe v naravi & 6 & 5,3 \\
\hline
\end{tabular}

Preglednica 1: Ocena samodejnega iskanja stavb

Od 101 najdene stavbe na območju je bilo glede na primerjavo podatkov nDMP in DOF050 ter obliko stavb v KS pravilno zajetih 38 stavb, 59 pa se jih je od podatkov razlikovalo v manjših detajlih. V večini teh 59 primerov gre za izpuščene nadstreške nad vhodnimi vrati stavb ali balkone, ki jih samodejni postopek ni zaznal, nekatere so posledica vegetacije (drevesa), ki prekriva dele stavbe. Dve stavbi sta bili zajeti z manjšo površino, kot jo imata v naravi. Razlog za izgubo površine teh stavb je vegetacija, ki je nad stavbami. Ena stavba je bila zajeta z napačno orientacijo. Os stavbe je bila določena napačno zaradi dreves, ki so onemogočila prepoznavanje celotne stavbe. Ena stavba je bila zajeta napačno, saj njena oblika v naravi ni pravokotna. Boljši rezultat pri tej stavbi bi pridobili, če bi v samodejni postopek vgradili iskanje premic, ki opisujejo obod stavbe, pod kotom $45^{\circ}$ glede na glavno os. Oceno pravilnosti samodejnega vektorskega zajema stavb prikazuje preglednica 2 .

\begin{tabular}{|l|c|c|}
\hline & Število & $\%$ \\
\hline Pravilno zajete & 38 & 37,6 \\
\hline Generalizirane & 59 & 58,4 \\
\hline Napačna površina & 2 & 2,0 \\
\hline Napačna orientacija & 1 & 1,0 \\
\hline Drugo & 1 & 1,0 \\
\hline
\end{tabular}

Preglednica 2: Ocena pravilnosti samodejnega vektorskega zajema stavb

Glede primernosti opisanega samodejnega postopka za zajem podatkov v topografsko bazo lahko ugotovimo, da rastrski podatki DMP s prostorsko ločljivostjo $0,5 \mathrm{~m}$, iz katerih je bil izdelan nDMP, niso uporabni za samodejni zajem stavb v topografske baze največjih meril ( $1: 5000)$. Stavbe $\mathrm{z}$ enostavno obliko in le deloma prekrite $\mathrm{z}$ vegetacijo samodejni postopek prepozna pravilno, več kot polovica stavb pa je zajeta brez manjših detajlov (nadstreški, balkoni). Rezultat bi lahko bistveno izboljšali, če bi imeli na voljo DMP z boljšo prostorsko ločljivostjo (npr. 0,25 $\mathrm{m})$. Odstopanja podatkov samodejnega zajema glede na dejansko stanje ne presegajo dolžine štirih pikslov (kar v našem primeru znaša $2 \mathrm{~m}$ ). Zato so ti podatki in opisani postopek primerni za zajem stavb v topografske baze merilih $1: 10000$ in manjših.

Po drugi strani lahko ugotovimo, da se je opisana metoda samodejnega zajema stavb na uporabljenih podatkih DMP in DOF050 izkazala kot primerna za iskanje sprememb in kontrolo pravilnosti zajema $\mathrm{v}$ topografske baze $\mathrm{v}$ merilu 1 : 5000. S samodejnim postopkom smo našli šest stavb, ki še niso bile evidentirane $\mathrm{v}$ KS, prav tako smo pravilno odkrili 22 prizidkov stavb in eno porušeno stavbo $(R P=6+22+1=29)$. Dveh dejanskih sprememb ( 2 prizidka $)$, ki so 
se v prostoru dejansko zgodile glede na KS, postopek ni odkril $(L N=2)$. V osmih primerih je postopek sprožil »lažni alarm « (šest neobstoječih stavb v naravi in dva napačno javljena prizidka, $L P=8$ ). Iz navedenih podatkov lahko izračunamo popolnost in pravilnost postopka za samodejno iskanje sprememb:

- $\quad$ popolnost $=93,5 \%$;

- pravilnost $=78,4 \%$.

Rezultat je povsem primerljiv z rezultati, ki jih je v raziskavi objavila organizacija EuroSDR. Postopek samodejnega iskanja sprememb so obravnavali z različnimi metodami in na različnih testnih podatkih, objavljeni rezultati pa znašajo od 78,9 \% do 98,8 \% za popolnost in od 45,1\% do $76,1 \%$ za pravilnost (Champion, 2009) pri primerjavi celotnih stavb kot objektov v analizi. Nekoliko boljše rezultate za pravilnost so pridobili s pikselsko primerjavo zajema in topografskih podatkov (do 96,5 \%). Slika 10 prikazuje izris rezultatov samodejnega iskanja sprememb v topografski bazi na delu, kjer je bilo največ sprememb. Z rumenimi krogi so označene stavbe, kjer je postopek odkril nove prizidke, z zelenimi krogi so označene nove stavbe, $\mathrm{z}$ rdečimi krogi pa stavbe, ki jih samodejni postopek ni našel. Rumeni obrisi predstavljajo rezultate samodejnega zajema stavb pred izvedeno vektorizacijo. Na sredini zgoraj je na sliki 10 viden tudi prizidek, ki ga samodejni postopek ni odkril.

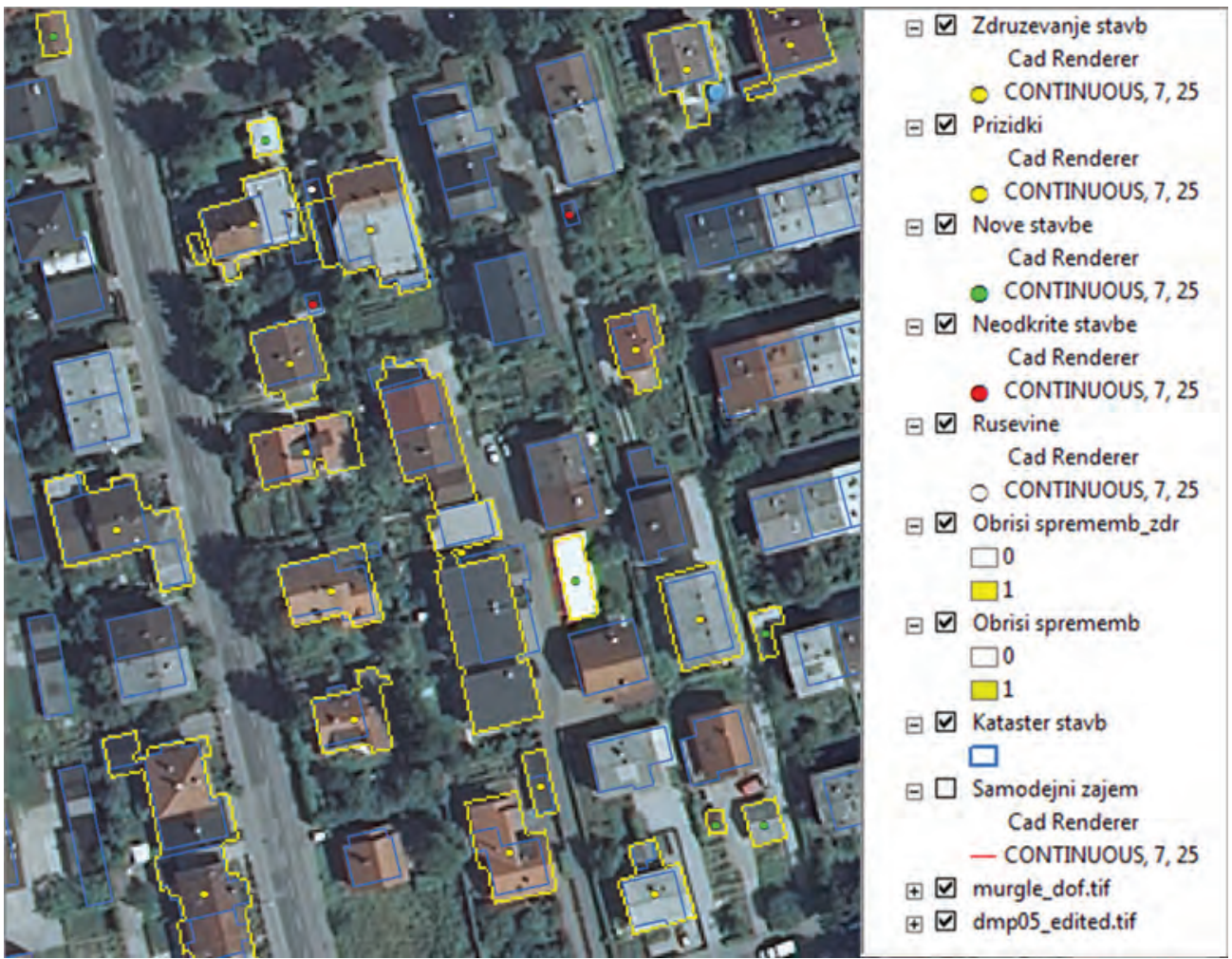


Opisana raziskava je pokazala, da je uporaba višinskih podatkov v kombinaciji z visoko ločljivimi slikovnimi viri pomembna pri odkrivanju sprememb v topografskih bazah podatkov. Z uporabljeno metodo smo našli večino dejanskih sprememb v prostoru in jo lahko ocenimo kot primerno za iskanje sprememb in kontrolo pravilnosti zajema podatkov v KS in DTK 5. Upravičeno lahko sklepamo, da visoka stopnja samodejnosti prinese tudi časovni prihranek pri iskanju sprememb glede na vizualni način, vendar tega $v$ raziskavi nismo podrobneje obravnavali. Metoda je manj primerna za neposreden zajem podatkov v topografske baze največjih meril (večjih od $1: 10000$ ) oziroma bi jo morali preskusiti še z uporabo DMP z boljšo prostorsko ločljivostjo.

\section{Literatura in viri:}

Champion, N. (2009). Detection of unregistred buildings for updating 2D databases. Euro SDR Official Publication $N^{\circ}$ 56. Amsterdam: Gopher.

Champion, N., Matikainen, L., Rottensteiner, F., Liang, X., Hyyppä, J. (2008). A test of 2d building change detection methods: Comparison, evaluation and perspectives. V: The International Archives of the Photogrammetry, Remote Sensing and Spatial Information Sciences, XXXVII/B4: 297-304.

Demir, N., Baltsavias, E. (2007). Object extraction at airport sites using DTMs/DSMs and multispectral image analysis. http://www.photogrammetry.ethz.ch/research/pegase/papers/PIA_DEMIR_BALTSAVIAS_eth_2.pdf(21. 10. 2010).

Dorninger, P., Pfeifer, N. (2008). A comprehensive automated 3D approach for building extraction, reconstruction and regularization from airborne laser scanning point clouds. Sensors 8(11): 7323-7343.

Gonzales, R. C., Woods, R. E., Eddins, S. L. (2004). Digital image processing using Matlab. New Jersey: Pearson Prentice-Hall.

Grigillo, D. (2010). Samodejno odkrivanje stavb na visokoločljivih slikovnih virih za potrebe vzdrževanja topografskih podatkov. Doktorska disertacija. Ljubljana: Fakulteta za gradbeništvo in geodezijo, Oddelek za geodezijo.

GURS (2001). Operativno navodilo za zajem podatkov o stavbah. Fotogrametrični zajem s povezavo z zemljiškim katastrom in registrom prostorskih enot, verzija 4.0. Geodetska uprava Republike Slovenije.

Haralick, R. M., Shanmugan, K., Dinstein, I. (1973).Textual features for image classification. IEEE Transactions on Systems, Man and Cybernetics 3(6): 610-621.

Heipke, C., Mayer, H.,Wiedemann, C., Jamet, O.(1997).Evaluation of automatic road extraction. V: International Archives of Photogrammetry and Remote Sensing, XXXII/3: 47-56.

Hofmann, A. D., Mass, H.-G., Streilein, A. (2002).Knowledge-based building detection based on laser scanner data and topographic map information. http://www.toposhop.admin.ch/pub/down/about/publi/ISPRS-2002.pdf(21. 10. 2010).

Holland, D. A., Sanchez-Hernandez, C., Gladstone, C. (2008).Detecting changes to topographic features using high resolution imagery. V: The International Archives of thePhotogrammetry, Remote Sensing and Spatial Information Sciences, XXXVII/B4: 1153-1158.

Kraus, K. (2007).Photogrammetry: Geometry from images and laser scans. Second Edition. Berlin: Walter de Gruyter GmbH\&Co.

Matikainen, L., Hyyppä, J., Ahokas, E., Markelin, L., Kaartinen, H. (2010).Automatic detection of buildings and changes in buildings for updating of maps. Remote Sensing, 2: 1217-1248.

Matikainen, L., Hyyppä, J., Kaartinen, H. (2004).Automatic detection of changes from laser scanner and aerial image data for updating building maps. Remote Sensing, V: The International Archives of the Photogrammetry, Remote Sensing and Spatial Information Sciences, XXXV/B2: 434-439.

Matlab (2010). Image processing toolbox. User's Guide. http://www.mathworks.com/help/toolbox/images/images_ product_page.html(14.10.2010).

Mayer, H. (2008).Objects extraction in photogrammetric computervision. ISPRS Journal of Photogrammetry and Remote Sensing, 63(2): 213-222.

Mayer, H., Hinz, S., Stilla, U.(2008).Automated extraction of roads, buildings and vegetation from multi-source data. $V: L i, Z$., Chen, J. and Baltsavias, E. (ur.) Advances in photogrammetry, remote sensing and spatial information sciences: 2008 ISPRS congress book. 213-226. London: CRC Press, Taylor \& Francis Group. 
Ono, Ak., Kajiwara, K., Honda, Y., Ono, At. (2007). Development of vegetation index using radiant spectranormalized by the irarithmeticmean. V: Proceedings of the Asian Conference on Remote Sensing, Asian Association on Remote Sensing. Kuala Lumpur, Malezija, 12.-16. november 2007.

Pfeifer, N., Rutzinger, M., Rottensteiner, F., Muecke, W., Hollaus, M. (2007). Extraction of building footprints from airborne laser scanning: Comparison and validation techniques. V: Proceedings of the Joint IEEE-GRSS/ISPRS Workshop on Remote Sensing and Data Fusion over Urban Areas, Urban 2007, Pariz, Francija.

Rottensteiner, F. (2008).Automated updating of building databases from digital surface models and multi-spectral images: Potential and limitations. V: The International Archives of the Photogrammetry, Remote Sensing and Spatial Information Sciences, Istanbul, Turčija, XXXVII/B3A: 265-270.

Rottensteiner, F., Trinder, J., Clode, S., Kubik, K. (2007).Building detection by fusion of airborne laser scanner data and multi-spectral images: Performance evaluation and sensitivity analysis. ISPRS Journal of Photogrammetry and Remote Sensing, 62(2): 135-149.

Sohn, G., Dowman, I. (2007).Data fusion of high-resolution satellite imagery and LIDAR data for automatic building extraction. ISPRS Journal of Photogrammetry and Remote Sensing, 62(1): 43-63.

Vosselman, G., Dijkman, S. (2001). 3D building model reconstruction from point clouds and ground plans. V: The International Archives of the Photogrammetry and Remote Sensing XXXIV, 3/W4: 37-44.

Vosselman, G., Gorte, B., Sithole, G. (2004).Change detection for updating medium scale maps using laser altimetry. V: The International Archives of the Photogrammetry, Remote Sensing and Spatial Information Sciences, Istanbul, Turčija, XXXV/B3: 207-212.

Samodejen zajem in iskanje sprememb v topografskem sloju stavb iz digitalnega modela površja in multispektralnegaortofota (2011).

Prispelo v objavo: 18. februar 2011

Sprejeto: 9. marec 2011

asist. dr. Dejan Grigillo, univ. dipl. inž. geod.

FGG - Oddelek za geodezijo, Jamova 2, SI-1000 Ljubljana

e-pošta:dejan.grigillo@fgg.uni-lj.si

doc dr. Mojca Kosmatin Fras, univ. dipl. inž. geod.

FGG - Oddelek za geodezijo, Jamova 2, SI-1000 Ljubljana

e-pošta:mojca.kosmatin-fras@fgg.uni-lj.si

doc. dr. Dušan Petrovič, univ. dipl. inž. el.

FGG - Oddelek za geodezijo, Jamova 2, SI-1000 Ljubljana

e-pošta:dusan.petrovic@fgg.uni-lj.si 